\title{
都市部におけるポリゴン型不浸透面積率データ を用いたHYPEモデルの流出予測精度向上に 関する研究 \\ STUDY ON A PRECISION IMPROVEMENT OF RUNOFF PREDICTION BY HYPE MODEL USING POLYGONAL IMPERVIOUS AREA RATIO DATA IN AN URBANIZED AREA
}

\author{
田内裕人 $1 \cdot$ 河村明 $2 \cdot$ 天口英雄 $3 \cdot$ OLSSON Jonas $^{4}$ \\ Hiroto TANOUCHI, Akira KAWAMURA, Hideo AMAGUCHI and Jonas OLSSON \\ 1学生会員 修（工）＼cjkstart首都大学東京 都市環境科学研究科（†192-0397 東京都八王子市南大沢1-1） \\ 2正会員 工博 首都大学東京 教授 都市環境科学研究科（干192-0397 東京都八王子市南大沢1-1） \\ 3 正会員 博（工） 首都大学東京 助教 都市環境科学研究科（广192-0397 東京都八王子市南大沢1-1） \\ 4非会員Ｐh.D., Swedish Meteorological and Hydrological Institute（SE-601 76 Norrkoping）
}

\begin{abstract}
A HYPE (HYdrological Prediction for the Environment) model considering impervious land cover in an urbanized watershed is set up to improve prediction precision of storm runoff. The set-up of the model is based on the Urban Atlas that is polygonal land cover data with impervious information. Firstly accurate impervious area ratios in a target watershed are calculated using the Urban Atlas, and the ratios are set to the HYPE model. Secondly, appropriate parameters to describe hydrological property in an urbanized area are implemented for the HYPE model. The model was applied for the watershed including urbanized area of Svedala, Sweden. It was demonstrated that impervious information obtained by polygonal impervious area ratio data contributed precision improvement of runoff prediction by HYPE model in urbanized area.
\end{abstract}

Key Words : HYPE model, Urban Atlas, runoff analysis, urban landscape, impervious area ratio

\section{1. はじめに}

河川および湖などの水辺環境の向上は，環境関連団体 や市民等らの強い要望であり，良好な状態を維持し保全 するには非常に大きな手間と時間が必要とされる．EU 諸国では，2000年に水域の水質向上を目指したWFD

(EU Water Framework Directive) 1) と呼ばれる条例が制 定された。 WFDへの取り組みには，流域内の水循環機 構を把握することが基本的かつ重要であり，土地利用変 化や地球温暖化の影響などが生じる様々な条件下におい て，流域からの流出量を予測可能な分布型流出モデルの 活用が有効である.

数万 $\mathrm{km}^{2}$ 以上の広域を対象とした流域への流出モデル の適用には，河川流量の存在しない未観測地域が多数含 まれており，流出特性に強く影響する土地被覆，土壤， 起伏などの地理的特性から流量を予測する，いわゆる
PUB（Prediction in Unguaged Basin）を目的とした技術が 必要である。例えば，HBVモデル2)はスウェーデン気象 水文研究所 (SMHI) が極域のPUBを目的に開発した分 布型流出モデルであり，流出計算の基本単位である計算 グリッドごとに土地被覆と土壌タイプを設定可能である. また小尻ら ${ }^{3)}$ が開発したHydro-BEAMは，計算グリッド 内の土地被覆の不均一性と土壌の鉛直構造の変化を考慮 し，個々の計算グリッドに対して複数の土地被覆面積率 と最大4層の土壌層を設定可能なモデルとなっている.

しかしながらグリッド型による対象流域のモデル計算で は，特に広域へ適用する際に計算速度の点で問題がある。 こうした背景から，SMHIはHBVモデルの後継モデルと して, 流域と地下水流れを考慮し構築した数十 $\mathrm{km}^{2}$ のポ リゴン型副流域を計算単位とする準分布型水文・水質統 合解析モデルのHYPE (HYdrological Predictions for the Environment）モデル4)を開発した。 HYPEモデルでは, 各副流域に複数の土地被覆と土壤タイプを面積率として 
容易に設定可能であり，GIS分野の技術的進歩とそれに 伴うデータの高精度・高解像度化にも対応可能なモデル 構造となっている. HYPEモデルでは, 日単位における 広域の流出現象の把握を目的としており, 計算の高速化 と流域モデル化の簡素化のために，流域の水文過程をで きる限り簡素な式で表現している．2007年にスウェーデ ン全域を対象としたモデルが開発されて以降は，世界各 地に拡張され，ヨーロッパ全域，北極圈やアフリカなど さまざまな地域の流出量予測で用いられてきた ${ }^{5)}$ 。現在 SMHIでは, 洪水流出解析一の適用を視野に入れ, 日単 位のHYPEモデルを拡張し, 時間単位のHYPEモデルの 開発を検討している.

流出特性に特に大きな影響を与える地理的要因として, 流域における都市部の有無がある，全流域面積に占める 都市部の割合が小さい場合でも，都市部の広範囲を占め る不浸透域からの雨水が地表面や雨水・下水道管路を介 して河川一直接排水されるため, 流域出口における降雨 時のピーク流量増大と洪水到達時間の短縮に寄与寸るの). このことから，対象流域に都市部を含む場合には，不浸 透域を考慮した流出モデルの設定が必要と考えられる. しかし従来，土地利用が錯雑な都市部を精緻に表現可能 なGISデータを広範囲で入手することが困難であったた め, 流出モデルに対して不浸透域を詳細に設定した事例 は, 数 $\mathrm{km}^{2}$ 程度の流域スケールを対象とした流出モデル7 ${ }^{8)}$ に限定され，広域を対象とした流出モデルでは，不浸 透域を無視するか，簡易的に扱うのみであった．例えば S-HYPEモデルは, 面積45万 $\mathrm{km}^{2}$ のスウェーデン国内を対 象とした最も高解像度なHYPEモデルであり，農村部を 湖, 池, 沼地, 水河, モレーン, 泥炭地, 露岩地帯, 農 地，針葉樹林，広葉樹林，草原の11種もの土地被覆に分 類し, 各土地被覆に対して水文特性を設定しているが, 都市部の分類は市街地と郊外のみであり, 不浸透域の影 響は考慮されていない4.

近年，浸透特性に基づく分類がなされ，かつ従来のグ リッド型と比較し個々の土地被覆形状を正確に表現可能 なポリゴン型土地被覆データの整備が進んでおり,

HYPEモデルのような広域を対象とした流出モデルにお いても，不浸透域の設定が可能となりつつある。例えば， 欧州環境機関が2010年に公開したUrban Atlasは, ヨー ロッパ各地の人口 10 万人を超える全ての都市部で入手可 能な高精度・高解像度のポリゴン型土地被覆データであ り, 各街区ポリゴンには衛星画像処理により得られた浸 透面積率が属性として与えられている9 . このことから Urban Atlasは, 都市部を含む流域を対象とした流出モデ ル設定に適した土地被覆データであり, Urban Atlasを用 いたHYPEモデルの設定手法を示すことはモデルの高度 化に資すると考えられるが，こうした研究は著者らの知 る限り承知していない.

そこで本研究では, HYPEモデルにおいて, 都市部に おける不浸透面積率データをUrban Atlasから設定する手
法（以下，U-HYPEと呼ぶ）を示すとともに，スウェー デン南部の小都市Svedalaを含む小流域を例にとり, UHYPEと従来のS-HYPEの流出量計算結果および河川流 量観測值との比較から流出予測精度を評価する. 本評価 結果から，HYPEモデルで正確な不浸透域面積率を考慮 することが，都市部の占める割合の大小に関わらず重要 であることを示す。

\section{HYPEモデルの概要}

\section{(1) モデルの基本構造}

図-1はHYPEモデルの基本構造を示している，HYPE モデルは対象領域を数 $\mathrm{km}^{2}$ 程度の副流域に分割し, 副流 域ごとに直接流出量や土㙵への浸透量, 蒸発散量を計算 する準分布型の物理モデルであり, 副流域内部の土地被 覆と土畩の不均一性について考慮可能なモデル構造と なっている. HYPEモデルの実流域への適用ではまず, 対象領域の土地被覆, 土壌, ポリゴン型副流域の各種 GISデータを用意する．ここでポリゴン型副流域の流域 界は, 各河川の流域と地下水流れを考慮し決定する. 次 いで，土地被覆データと土壌データを重㸚合わせ，耕作 地 (シルト土壌) や針葉樹林 (モレーン土㙥) といった 土地被覆と土壌の組み合わせを土地被覆一土壌クラスと して抽出する. 個々の土地被覆一土壤クラスには，上層

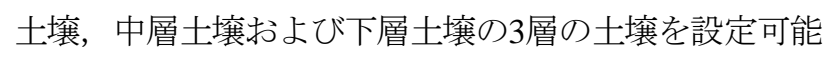
となっており (図-1），土壌層ごとに層厚，萎れ点，圃 場容水量, 有効間隙率などの土㙵物理パラメータ, 直接 流出量や土壤浸透量, 地下水位変動, 蒸発散量などを計 算するための水文パラメータを設定する. 最後に, 各副 流域に対して, 個々の土地被覆一土壤クラスが占める面 積率を計算し, 副流域の属性として与えて対象流域をモ デル化する.

\section{（2）流出計算フロー}

図-2はHYPEモデルが対象とする水文諸過程を示して いる. HYPEモデルでは地表面流出, 土壌各層からの中 間流出や浸透量, 蒸発量などの基本的な水文量に加え, 積雪・融雪過程や湖内部の水・栄養塩循環, 水の移動に 伴う農地等からの栄養塩輸送も合わせて解くことが可能 である. HYPEモデルのシミュレーションで必要な気象 データは, 副流域ごとの日降水量および日平均気温であ

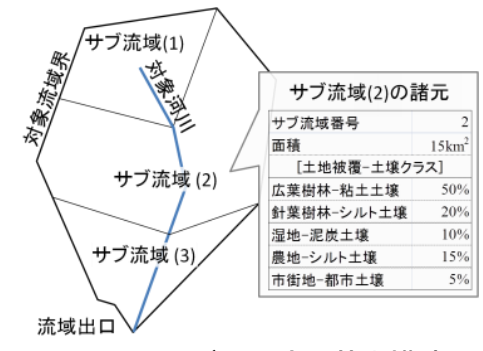

図-1ＨYPEモデルの流域基本構造. 


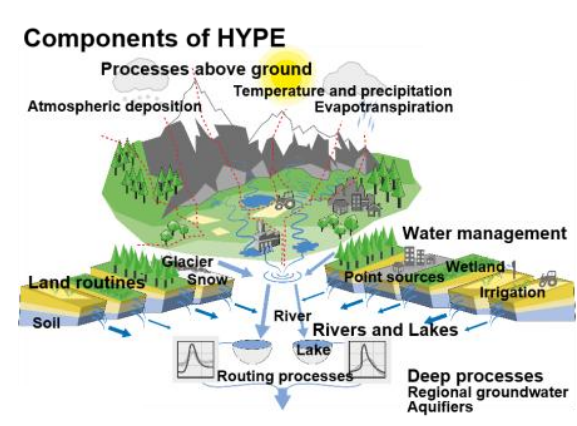

図-2ＨYPEモデルで扱う諸水文過程.

り，降水量は気温が0度以上の場合には降雨として，0度 以下の場合には降雪として, 副流域を構成する土地被覆 一土壌クラスに与えられる。.以下では，副流域内の $1 つ$ の土地被覆一土壤クラスにおける雨水の流れについて述 ベる.

まず，日降雨は土地被覆一土壤クラスごとに設定され た配分パラメータに基づき，地表面流出成分，マクロ ポール流成分および土㙵浸透成分として配分される．地 表面流出成分はただちに副流域出口に排水され，降雨当 日の副流域出口の河川流量増加に寄与寸る. マクロポー 儿流成分は地下水に直接涵養され，地下水位上昇とこれ に伴う地下水流出量増加に寄与する。 土䁃浸透成分につ いては, これが日最大浸透能よりも小さく, かつ上層土 壌において不飽和の状態が維持される場合には，すべて 上層土壤へと浸透し上層土䁃間隙を満たすが，これら条 件を満たさない場合には余剩水が地表面に残り次の日の 流出計算にまわされる，上層土㙵では，水分量が萎れ点 を上回る場合には蒸発散量の夕が，圃場容水量を上回る 場合には蒸発散量, 直接流出量, 中層土壌への浸透量が それぞれ計算される. なお蒸発散量, 直接流出量, 中層 土壤への浸透量がすべて計算された後に上層土壌に残つ た水分量については，余剩水として次の日の流出計算に まわされる. 次いで, 中層土壌における蒸発散量, 直接 流出量, 浸透量は，上層土壤と同様の流れで計算される. 一方，下層土壌では，土壌からの蒸発散量が地表面から の深さに対して指数関数的に減少するとの仮定から，下 層土壤からの蒸発散を微小として無視しており, 直接流 出量と地下水面上昇のみを計算する。 また，下層土㙥は 定常的に地下水がある層として扱われ，パラメータで設 定した深さ以上に存在する水のみが河川に流出する。 土 㙥からの直接流出量, 浸透量, 蒸発量や融雪過程等の詳 しい計算方法と各種パラメータは，参考文献4)を参照さ れたい.

\section{（3）モデルのバージョンと対象流域}

図-3に本研究の対象とするSege川上流域の位置および その概略図を示す．本研究では，HYPEモデルとしてSHYPEのver. 4.8.0を用いることとする. S-HYPEは副流域 のGISデータとして，SMHIにより整備されたSwedish Water Archive ${ }^{4)}$ を用いている. Swedish Water Archiveで

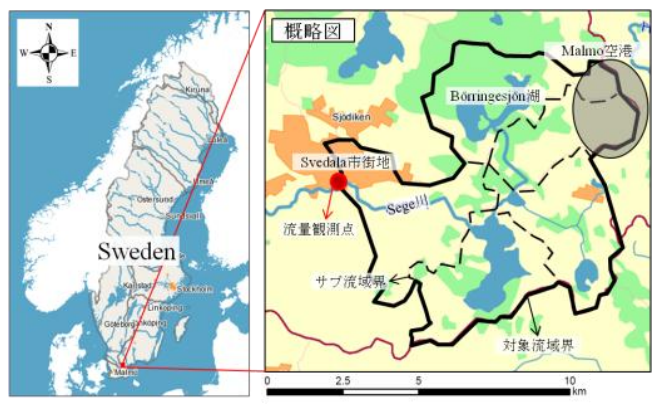

図-3 スウェーデン全域とSege川上流域の位置（左）および その概略図と副流域（右）

は, 河川流域および地下水の調査に基づいて，45万 $\mathrm{km}^{2}$ 程度のスウェーデンをおよそ38,000個のポリゴン型副流 域に分割しており, S-HYPEの副流域平均面積は約 $12 \mathrm{~km}^{2}$ でHYPEモデルとしては最大の解像度となる。 またSHYPEでは，土地被覆データとして欧州環境機関が配備 した100mグリッドのCORINE Land Cover ${ }^{10)}$ を，土壌デー タとしてスウェーデン地質調査所が提供するSGU soil database ${ }^{11)}$ をれぞれ用いている（図-4）。

本研究で研究対象としたSege川はスウェーデン南部ス コーネ地方の湖Börringesjönにその源を発し，人口約 1 万 人の小都市Svedalaの南部およびスウェーデン第三の都市 Malmoの北側を順次流下しÖresund海峡に注ぐ河川であ る. Sege川の流路延長は約 $40 \mathrm{~km}$, 流域面積は約 $200 \mathrm{~km}^{2}$ となっており, 流域最高点は海抜 $49 \mathrm{~m}$ と低く流域のほと んどが低平地となる。本研究においては，Sege川上流域 の流域面積 $52.2 \mathrm{~km}^{2}$ をU-HYPEの構築対象流域に設定した. 本対象流域の流域出口付近にはSvedalaの市街地が，上流 域にはMalmo空港があり，それぞれ流域からの直接流出 量増加に寄与寸ると考えられるが，対象流域の中流付近 に複数の湖があり, Malmo空港からの直接流出はこれら の湖へ流れ込むため, 流量観測点における降雨時のピー ク流量増加に対しては, Svedala市街地からの直接流出の 寄与がより大きいと考えられる.

\section{3. 流域のモデル化}

\section{（1）土地被覆一土壤クラスの設定}

図-4は, SvedalaにおけるUrban Atlas, CORINE Land CoverおよびSGU Soil databaseを示している. Urban Atlas では都市部を対象とし，1/50000地形図・衛星画像・ナ ビゲーションシステムの道路ネットワークデータ等を用 いて対象領域を22個の土地被覆区分に分割・分類してい る. またUrban Atlasでは各街区や道路などの各土地被覆 がポリゴン形状で表現されており, その水平方向の精度

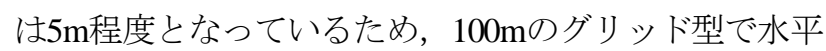
精度が40mのCORINE Land Coverよりも精緻なデータと いえる. さらにUrban Atlasでは, 建物用地に対して不浸 透面積率が属性として与えられている.このためUrban Atlasは, CORINE Land Coverと比較し都市部の浸透特性 

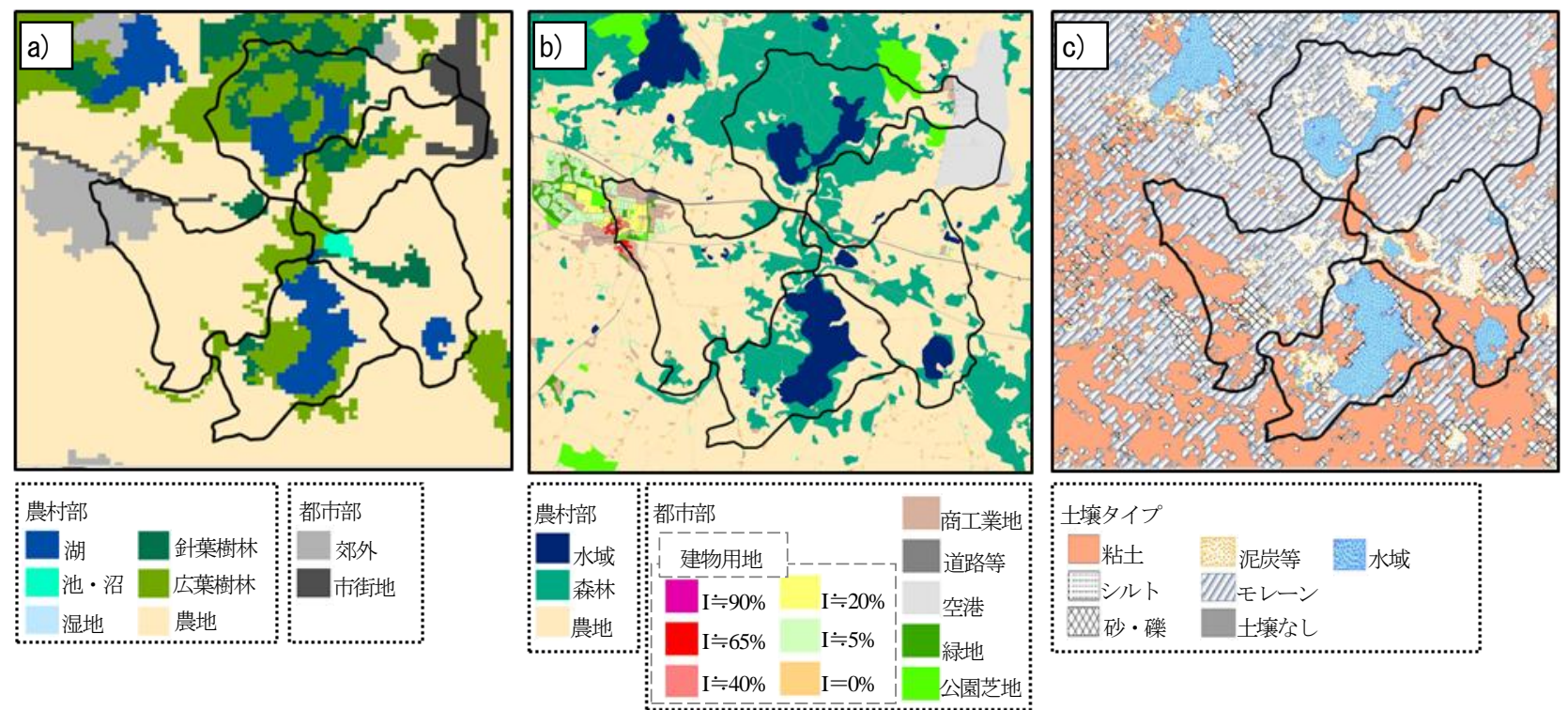

図-4 Sege川上流域のa) Cor ine Land Cover とb) Urban Atlasの土地被覆区分およびc) SGU Soil databaseの土壤タイプ分類. 把握に適したデータであるといえる.

次いで図-4 a) のSvedala市街・Malme空港以外の農村 部に着目すると，都市部と比較し土地被覆が空間的に均 一で，CORINE Land Coverでも土地被覆を十分に表現可 能であることが見て取れる．またCORINE Land Coverで は森林を広葉樹林，針葉樹林に分けているが，Urban Atlasでは植生による分類がない．さらに都市部の外では Urban Atlasの構築対象領域外之なる場合も考えられる.

これらの理由から，CORINE Land Coverのほうが農村部 の土地被覆データとして有利といえる。 そこで本研究で はまず図-5 a)のように, CORINE Land Coverによって 対象流域を都市部と農村部に分類し, 次いで図-5 b) の ように都市部におけるUrban Atlasの22種土地被覆区分を 抽出し，浸透特性に従い不浸透域，建物用地浸透域，緑 地，公園芝地の 4 種の土地被覆種別に再分類した。 ここ で建物用地については，Urban Atlasの不浸透面積率に従 い，不浸透域と建物用地浸透域の両方の分類おける面積 計算に用いている．例えば不浸透面積率が $90 \%$ の建物用 地であれば，その建物用地の面積の $90 \%$ が不浸透域とし て，10\%が建物用地浸透域の面積として計算される。 ま た商業・工業用地および道路等の交通関連施設に関して は，完全な不浸透域として扱っているが，空港について のみ, 航空写真により $30 \%$ 程度が不浸透域と考えられた ため, 不浸透域を $30 \%$ とし, 空港の不浸透域以外は建物 用地浸透域と同様に扱うこととした。 なお農村部は図-5 c)のように, 従来のS-HYPEと同様にCORINE Land Coverの土地被覆区分に従い，6種類の土地被覆種別に分 類した。これらの土地被覆種別を組み合わせ，U-HYPE の土地被覆データを生成した（図-5 d)）。表-1は, Svedala流域におけるU-HYPEで設定した各土地被覆種別 の面積率を示寸。本流域の都市部は対象流域全体の5.7\%, 特に本研究で新たに設定した不浸透域は2.6\%のみであり, 大部分が農村部となった。特に支配的な土地被覆種別は

農耕地であり，流域の56\%を占める。なお，U-HYPEで はS-HYPEと同様に土壤データとしてSGU Soil Database を用い，土地被覆種別と組み合わせ土地被覆-土壌クラ スを設定しているが，土地被覆が不浸透域となる領域で はSGU Soil Databaseの土壌タイプを用いず，独自に「不 浸透タイプ」を設定している.これについては3. (2)に て述べる。

\section{(2) モデルパラメータの設定}

表-2は本研究での土地被覆種別ごとのパラメータの設 定方法を示している. 本研究では，U-HYPEとS-HYPE の間に土地被覆種別の違いがない農村部に対しては，UHYPEに従来と同じパラメータを設定した。また都市部 については，4種の土地被覆種別のうち，「緑地」は農 村部の「広葉樹林」と，「芝地公園」は「草原」と水文 学的特性がそれぞれ類似すると考え，「緑地」について は「広葉樹林」と同じパラメータを，「芝地公園」につ いては「草原」と同じパラメータをそれぞれ設定するこ

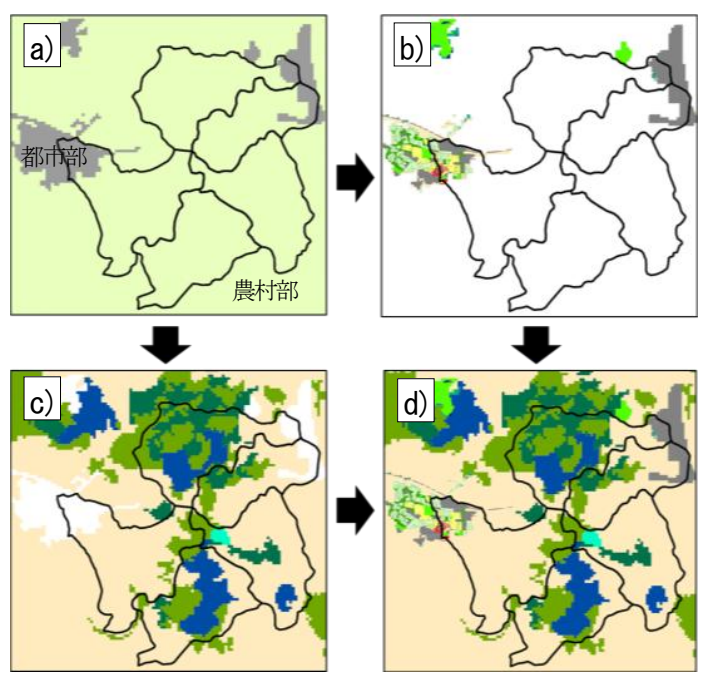

図-5 Urban AtlasとCorine Land Cover両方を用いた土地被覆 データの作成方法. b)，c)の凡例は図-4と同様. 
表-1 Svedala流域のCORINE Land Cover, Urban AtlasおよびSGU soil databaselによる各土地被覆一土壌クラスの面積率[\%]

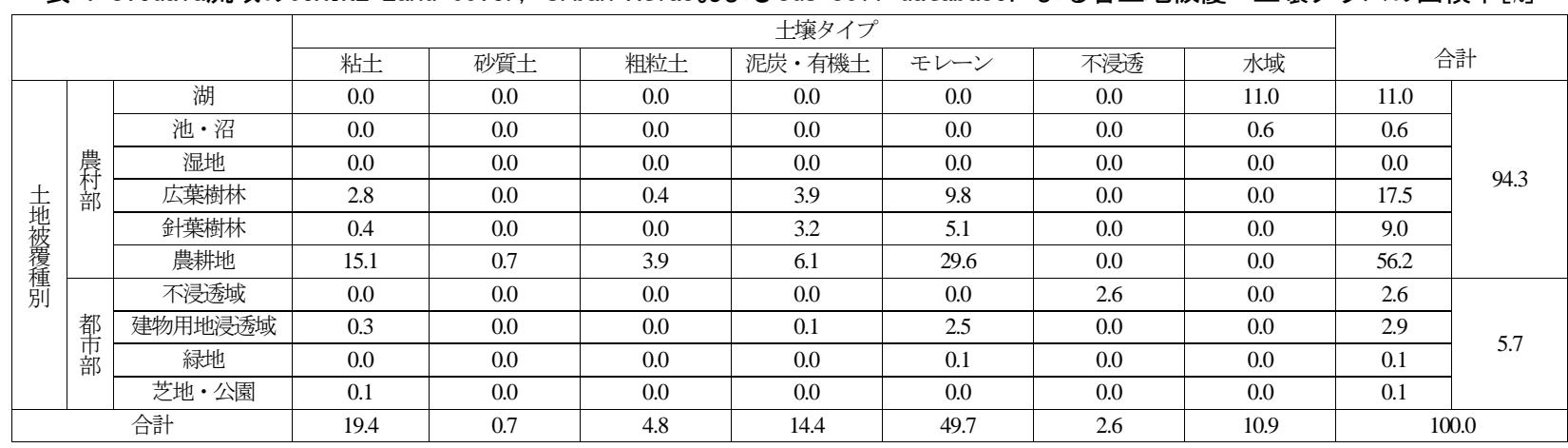

ととした。 さらに「建物用地浸透域」については，従来 のS-HYPEで同種の土地被覆種別が与えられてはいな かったが，S-HYPEの「郊外」に設定された水文学的特 性が近かったことから，「郊外」の土地被覆種別と同じ 水文パラメータを用いた. なお，これらの土地被覆種別 下の土壌の水文学的特性については，S-HYPEと同様に SGU Soil Databaseを用いて設定している.

一方，抽出した「不浸透域」については，S-HYPEモ デルで類似の水文学的特性をもつ土地被覆種別が設定さ れていない，そこで本研究では，不浸透域の土地被覆一 土壤クラスを新たに設定し，パラメータを以下の考え方 に従い設定した。図-6は，本研究で考慮した不浸透域の 水文学的特性を示している. 不浸透域では雨水浸透が基 本的には生じず, 雨水の大部分は地表面もしくは雨水・ 下水道管路を介する直接流出となることを考慮し，不浸 透域の土壌タイプ「不浸透タイプ」における上層土壌に は，間隙，浸透量，マクロポール流量が極小かつ地表面 流出量が大きな「不浸透層」の特性を持たせた。 なお， HYPEモデルでは副流域ごとに気温や降水量などをパラ メータにより補正可能であるが，U-HYPEではS-HYPE から土地被覆に関するパラメータのみを変更し，補正パ ラメータについてはS-HYPEに設定されたものと同じ值 を用いた。

\section{4. 流出解析とモデル検証}

本研究では，2001年1月1日から2013年12月31日までを モデル計算の対象期間として流出量の算定を行い, UHYPEとS-HYPEによって対象流域出口のSvedala流量観 測点（図-3）における流出量を計算するとともに，計算 結果について同観測点における観測日平均流量との比較 を行った. 本研究において用いた入力気象データは，ス ウェーデン国内の定点観測データを空間内挿し得られた 各副流域の日降水量・日平均気温データ ${ }^{12)}$ である. 図-7 a)は，2010年1月1日から2013年12月31日までの期間にお ける，Svedala流量観測点での観測流量とU-HYPE，SHYPEでのシミュレーション結果を，また図-7 b) は，融 雪などの影響が少なく直接流出の河川流量への寄与が大 きいと考えられる夏季の解析結果の一例として，2013年
7月1日から同年9月30日まで同図を示している。まず図一 7 a)に注目すると, Svedalaでは12月から4月までの河川 流量が7・8・9月の夏季と比較し多いことが見て取れる。 これはスウェーデン南部が冬季多雨気候区に属すること に加え，3・4月には融雪による河川流量の増加があるた めと考えられる。こうした季節スケールの傾向はUHYPEとS-HYPEの両方で表現されており，都市部を考 慮した影響は大きくは現れていない.

一方，図-7 b）の夏季に着目すると，たとえば期間 $\mathrm{A} \cdot \mathrm{B} ・ \mathrm{C} ・ \mathrm{D}$ のような降雨が観測された日において，UHYPEでは観測と同様に流量ピークが発生していること が見て取れ, 流量ピークが発生しないS-HYPEと比較し 良好な解析結果となっている。 また，U-HYPEでは期間 $\mathrm{B}$ のような日降雨が $10 \mathrm{~mm}$ 程度以下の小さなイベントに おいてもピーク流量が発生している.このことは, 日降 雨10〜20mm程度以下の少雨においても，U-HYPEが, 対象領域のわずか $2.6 \%$ にすぎい不浸透域の影響を，日 平均 $0.2 \sim 0.3 \mathrm{~m}^{3} / \mathrm{s}$ のピークが現れるという形で正しく再 現可能であることを示している. 次いで洪水到達時間に 着目すると，期間A・Dのように，U-HYPEでは洪水到 達時間が観測值よりも早いことが見て取れる。これは HYPEモデルの設計において, 副流域内の洪水到達の遅 延を考慮していないためではないかと考えられる。また

表-2 本研究のS-HYPEでのパラメータ設定方法.

\begin{tabular}{|c|c|c|c|}
\hline \multicolumn{4}{|c|}{ 土地被覆（農村部） } \\
\hline 湖 & 0 & 広葉樹林 & $\bigcirc$ \\
\hline 池・沼 & 0 & 針葉樹林 & 0 \\
\hline 湿地 & 0 & 農耕地 & $\bigcirc$ \\
\hline \multicolumn{4}{|c|}{ 土地被覆（都市部） } \\
\hline 不浸透域 & $\times$ & 緑地 & $\triangle$ (広葉樹林) \\
\hline 建物用地浸透域 & $\triangle$ (郊外) & 芝地・公園 & $\triangle$ (草原) \\
\hline
\end{tabular}

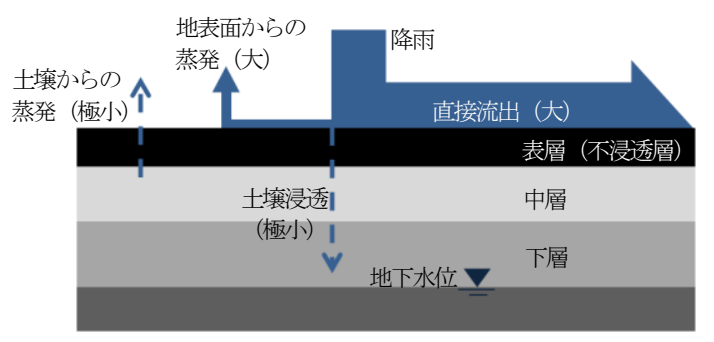

図-6 考慮した不浸透域の水文学的特性 

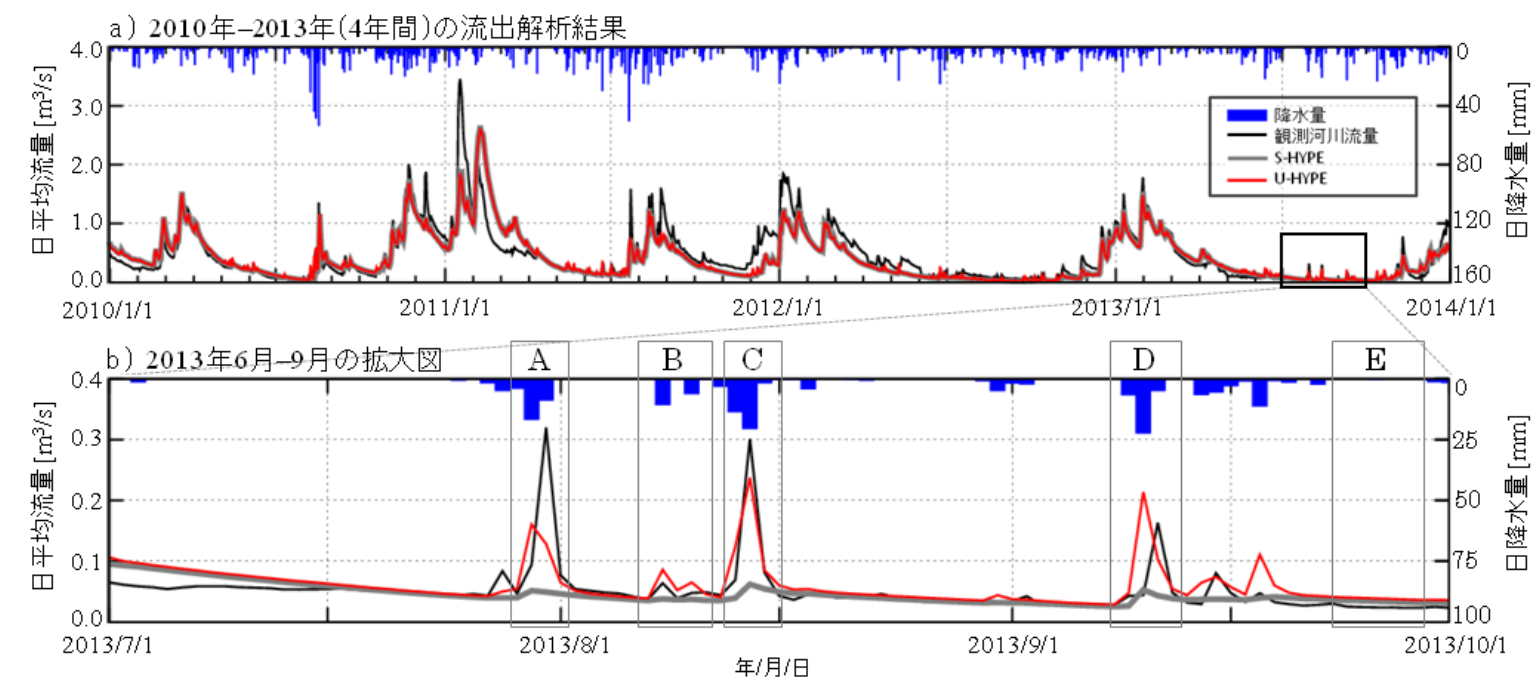

図-7 Svedala河川流量観測点の流量観測值とU-HYPEおよびS-HYPEによよる河川流量の比較.

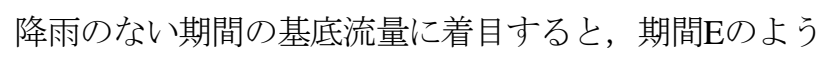
に若干の過大評価がみられる期間がある。しかし，UHYPEの流出量はS-HYPEと比較し，概ね観測に近いも のとなった. これらの結果から, 本研究で提案した手法 を用いてHYPEモデルで不浸透域を考慮することで，流 出計算の精度が向上したと考えられる.

\section{5. むすび}

本研究では，SMHIが開発した広域統合流出モデルで あるHYPEモデルを対象とし, ベクトル型高精度土地被 覆データであるUrban Atlasから都市部の不浸透域を抽出 し，不浸透域の影響をモデル計算に反映させた．本モデ ルをスウェーデン南部の都市Svedalaを含む流域に適用し， 日流量観測データと比較を行いモデルの再現性を検証し た結果，季節などの長期スケールにおいてはU-HYPEと S-HYPEに差が見られないものの, 夏季における降雨時 のピーク流量について再現性が向上し, 特に降雨強度の 小さな降雨イベントで顕著な向上が見られた. 規模の小 さな降雨イベントでの流量再現精度の向上は, ファース トフラッシュをはじめとする都市からのノンポイント污 染を解析する際に重要であろう。本結果は, HYPEモデ ルの適用において, 都市の占める割合が小さな流域につ いても，特に都市の大部分を占める不浸透域を正確に設 定する必要があることを示唆している. 今後の課題とし ては, S-HYPEの拡張として提案したU-HYPEモデルで は洪水到達時間が観測と比較し早いこと，および基底流 量の過小評価について原因究明およびその改善を行い, さらなる精度向上を図る予定である。 また現在検討中の 時間単位のHYPEモデルにおいても，Urban Atlasを用い た流域のモデル化を施す予定である.

謝辞 : 本研究を遂行するにあたり, 科学研究費(基盤研 究 (C)，代表 : 天口英雄, 課題番号 : 25420530)の補 助を受けました. ここに記して深謝申し上げます。

\section{参考文献}

1) EU Water Framework Directive, http://ec.europa.eu/environment/ water/water-framework/index en.html, アクセス日 : 2015/9/28.

2) Bergstörm, S.: Development and application of a conceptual runoff model for Scandinavian catchments, SMHI Reports RHO, No.7, Norrköping, 1976.

3) 小尻利治, 黒田良人, 東海明宏 : GISベースでの水環境シ ミュレーションと環境評価モデルの開発, 第5回地球環境シ ンポジウム講演集, pp.209-214, 1997.

4) Lindström, G., Pers,C.P., Rosberg, R., Strömqvist, J. and Arheimer, B.: Development and test of the HYPE (Hydrological Predictions for the Environment) model - A water quality model for different spatial scales, Hydrology Research, Vol. 41(3)-4, pp. 295-319, 2010.

5) SMHI Hydrology Research, http://www.smhi.se/en/research/ research-departments/hydrologyl, アクセス日 : 2015/9/23.

6) W.D. Shuster, J. Bonta, H. Thurston, E. Warnemenda and D. R. Smith.: Impacts of impervious surface on watershed hydrology: A review, Urban Water Journal, 2:4 pp.263-275, 2005.

7) L. Cuo, D. P. Lettenmaier, V. Mattheussen, P. Storck and M. Wiley: Hydrologic prediction for urban watersheds with the Distributed Hydrology-Soil-Vegetation Model, Hydrological Processes, Vol.22, pp.4205-4213, 2008.

8) Amaguchi, H., Kawamura, A., Olsson, J. and Takasaki, T.: Development and testing of a distributed urban storm runoff event model with a vector-based catchment delineation. Journal of Hydrology, vol.420-421, pp.205-215, 2012.

9) Urban Atlas, http://www.eea.europa.eu/data-and-maps/data/urbanatlas, アクセス日 : 2015/9/23.

10)CORINE Land Cover, http://www.eea.europa.eu/ publications/COR0-landcover, アクセス日 : 2015/9/23.

11) SGU soil database, http://www.sgu.se/en/,アクセス日 : 2015/9/23.

12) Johansson, B.: Estimation of areal precipitation for hydrological modeling in Sweden, Thesis (Dr), Earth Science Center, Department of Physical Geography, Göteborg University, A76, 2002.

(2015. 9. 30受付) 